\title{
Approach to Campus Sustainability at Universiti Kebangsaan Malaysia (UKM): A Review
}

\author{
H.I Kwami ${ }^{1}$, A.I. Che-Ani ${ }^{2}$, N.M. Tawil ${ }^{3}$, M.M. Tahir ${ }^{4}$, H. Basri ${ }^{5}$ \\ 1,2,3,4 Department of Architecture, Faculty of Engineering \& Built Environment, Universiti \\ Kebangsaan Malaysia, Bangi 43600, Malaysia \\ ${ }^{5}$ College of Civil \& Structure Engineering, Faculty of Engineering \& Built Environment, Universiti \\ Kebangsaan Malaysia, Bangi 43600, Malaysia
}

\begin{abstract}
Triple Bottom Line of the Green Agenda 21 is essential in meeting the sustainability needs of the present and future generations in any University system. The paper reviewed existing campus sustainability issues along the Triple Bottom Line factors of People, Planet and Profit which largely overlooked the brown agenda 21 of Equitable, Viable and Bearable factors. In order that a sustainable teaching and learning process take place, the paper argued that the pursuit of Environmental, Social and Economic concerns are to be integrated with human welfare issues of Equity, Viability and Bear ability. To achieve the above objective, the researcher's employed visual observations on the interactions between human and the biophysical environment as well as the use of relevant literature. The findings of the study showed that a sustainably holistic campus can be achieved if the University improved on the integration of its environmental concern and human welfare issues. This study underscores the importance of care of human resources for being what they are and not a commodity. The implication of the later negates the principles of fairness, equity and justice. The paper concluded that in order to have a holistic approach to campus sustainability, the welfare of the University community should be of paramount importance.
\end{abstract}

\section{Introduction}

Agenda 21 was aimed at achieving an overall sustainable development worldwide. Higher educational institutions were therefore expected to act as trailblazers in the realization of this mission [1]. It is a platform to build upon for building knowledge about sustainability and transferring it into actions [2]. The Brundtland [3] defined "sustainable development as the one that meets the needs of the present without compromising the needs of the future generations to meet their own needs" by focusing on a balance of environmental, social and economic factors [3]. It contains two key words; 1) needs, being the essential needs of the world's poor, to which overriding priority should be given and 2) the idea of limitations imposed by the state of technology and social organization on the environments ability to meet present and future needs. It involves devising a social and economic system, which ensures that these goals are sustained; real incomes rise, educational standard increase, health of the nation improves, and general quality of life is advanced. This improves the quality of human life whilst living within the carrying capacity of the ecosystem. The report writes "our inability to promote the common interest in sustainable development is often a product of the relative neglect 
of economic and social justice". It further states that while "a world in which poverty and inequality are endemic will always be prone to ecological and other crisis.

The University leaders for sustainable future ULSF [4] stated that Talloires declaration of 1990 [5] was the first official statement on campus sustainability and environmental literature which was signed by leaders of the schools that depicts the scientific concern over issues such as the unprecedented scale and speed of environmental degradation as well as the depletion of the natural resources and the significance of the universities combating the unsatisfactory situation. Sustainability tracking assessment and rating systems (STARS) formation in 2006 was the second important effort made on campus sustainability. STARS focuses on three major categories of activity; 1 Education and research 2 Operations, and 3 Administration and finance [6].

\section{Sustainability/Sustainable Development Concepts}

Sustainable development (SD) has various interpretations, depending on the field of endeavour [7]. However, defined Sustainable development is a continuous process of maintaining a dynamic balance between demand of people for equity, prosperity and quality of life, and what is ecologically possible. Sustainability on the other hand is the condition, which would allow the continued existence of Homo sapiens and provide safe, healthy and productive life in harmony with nature and local cultural and spiritual values. Sustainable development requires meeting the basic needs of all and extending to all the opportunity to satisfy their aspirations for a better life". The objective of sustainability or sustainable development is to sustain the human species, to support, to keep alive, and to keep going. The key concern of sustainability is to keep planetary conditions favorable for human life at a global as well as local level. Therefore, all will live a safe, healthy and productive life in harmony with nature and local cultural and spiritual values when there is a balance in the three aspects of economic, social and environment [8].

The 3 pillars of sustainable development are, people (social development), planet (ecological protection), and prosperity (economic development) or popularly known as the triple bottom line concept of people, planet and profit, abbreviated and phrased as TBL, 3BL, PPP, 3P, 3PS, e t c. The triple bottom line was articulated by [9] in his publication called "social audit" and coined by [10] book in 1998 titled "Cannibals with Forks: the triple bottom line $21^{\text {st }}$ century business" [11].

The "people" is concerned with (human capital), social responsibility, social development, social equity, social needs, human system, fair beneficial business practices to people, community and region, well- being of corporate labor and enhance human comfort, health and overall quality of life.

The "planet" is concerned with (national capital), sustainable environment practice, reduce environmental and climatic impact on local and global environment, reduce ecological footprint, reduce energy and water waste, conduct a life circle assessment of product from cradle to grave, external environment, environmental conservation and biodiversity protection, environmental needs, planet.

The "profit" is concerned with (financial capital), business sense, economy and health, prosperity, priority, benefit to the economy, economic needs, economic development, reduce energy, water and operating cost, optimize life circle, economic performance, support local economy and high level of employment. Economic security, more goods and services, fewer resources, improve employee productivity, economic value, money, money, money.

Arguments in support of the TBL sustainable development concept is that it can; lead to financial profitable riches for organizations by adding ecotourism to the market; help develop profitable methods to assist existing NGOs with their missions; provide services with some benefit to serve environment and people unattended to. It leads to the adoption of a new business concept in the realm of social entrepreneurialism that are financially profitable, socially genetically and economically 
sustainable that is within the realm of ethical trade and sustainable practices for all their producers and services.

On the other hand, argument against TBL is that it is harmful by diverting business attention away from its core competency, so business should not take concern with issues outside its expertise as long as it does not do obvious harm to people of planet. The concern for social and environmental matters is rare in poor societies because of hunger, poverty and deprivation so to them its food first and not protection of the environment. It is difficult to apply TBL in monetary terms because its benefits cannot, directly be measured to the society and environment. It is also argued that TBL is an attempt by exploitative corporations to avoid logistic and taxation by generating a fictitious peoplefriendly and eco-friendly image for public relation purpose [9].

\section{Campus Sustainability/Sustainable Development Concepts}

Velaquez et al [12] defined a sustainable university as a higher educational institution as a whole or a part that addresses, involves, and promotes, on a regional, or global level, the minimization of negative environmental, economic, social and health effects generated in the use of their resources in order to fulfil its functions of teaching, research, outreach, partnership and stewardship in ways to help society make the transit to sustainable life style under, 1 Planning and engagement, 2. Operation, 3. Education and resources and extend its reach to the local community [13].

Because they are a centre of knowledge, universities around the world have become increasingly concerned with sustainability issues [14].However, sustainability issues are faced with many problems, that the main barriers to campus greening is lack of; positive attitude; financial resources, and environmental education within the campus community. Positive attitude to Sustainable schools benefit the outdoor and indoor environment, students, teachers, and administrators because they are energy and water efficient, use renewable energy and green materials to the fullest extent possible. They partake in the reduction of pollution and landfill waste [15]. It is in line with the above that this paper tried to integrate the six elements of green and brown agendas for Universiti Kebangsaan so as to have a holistic approach to sustainability.

Agenda 21 is a $\mathrm{U}$ N comprehensive blue print of action to be taken globally, nationally and locally by organizations, governments and major groups in every area in which human impact on the environment. It consisted of the Green Agenda 21 and the Brown Agenda 21. Green Agenda tends to focus on the problems of affluence and over consumption management and development more pressing in the advanced countries. It concentrated on reducing the environmental impact of urbanbased production, consumption and waste-generation on natural resources and ecosystem and ultimately on the worlds life-supporting system. Brown Agenda 21 focuses on alleviating poverty and underdevelopment in poor countries while protecting the environment, emphasizes the need to reduce the environmental threats to health that arise from poor sanitation conditions, crowding, inadequate water provision, hazardous air and water pollution and local accumulation of solid waste more pertinent to poor countries. It emphasizes that human population; consumption and technology are the primary driving forces of environmental change. This is to reduce waste full and inefficient consumption pattern while encouraging increased but sustainable development in others [8].

Agenda 21 states that education is critical for promoting sustainable development and improving the capacity of all people to address environmental and developmental issues. The leaders of higher education institutions and their colleges must make sustainable development a central academic and organizational focus in order to create a just, equitable and ecologically sound future. This requires the generation and dissemination of knowledge through interdisciplinary research, teaching and policymaking capacity building and technology transfer [14]. Figure 1.0 below shows a typical campus sustainability development concept. 


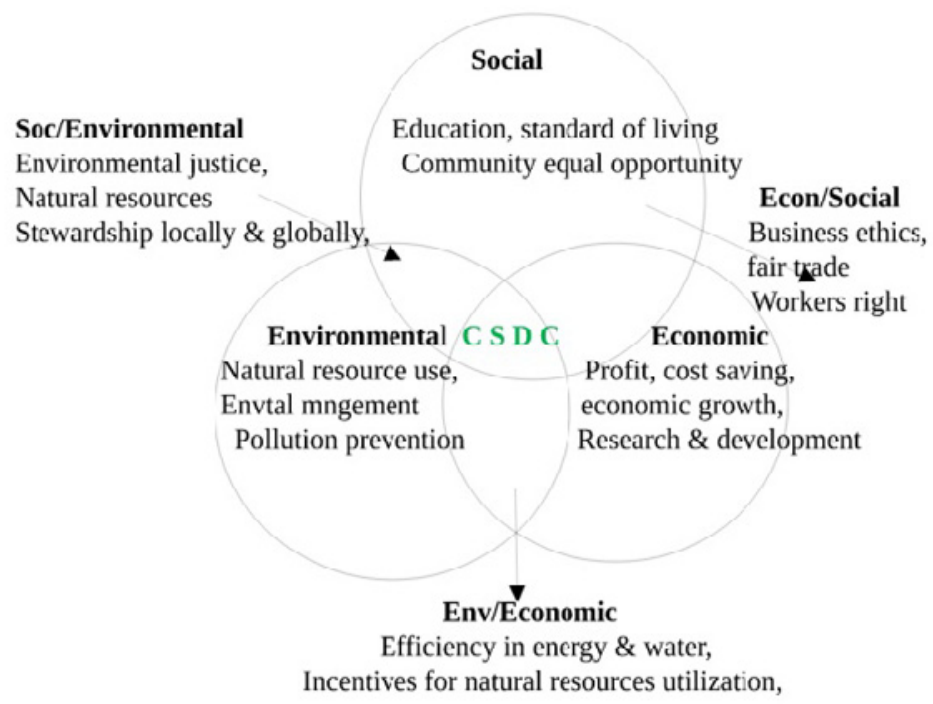

Figure 1: Adapted from University of Michigan sustainability association 2002 Campus sustainability development concept.

\section{UKM Sustainability Initiatives}

The university research efforts on sustainability issues, of energy, and green architecture for long and short terms are handled by the management, academia, Institutes (LESARI 1994 and SERI 2005). Specifically the institute's aims were to; deal with environmental and developmental issues; enhance human resource through skills development and training; responsible for acquiring sources of renewable energy resources [16]. These organs help to create spaces for physical and social activities that are conducive for work, play and learning. The university is in principles committed to the implementation of the sustainable development by 2020 [17].

\section{Holistic Approaches to Sustainability}

The paper argued that in the pursuit of campus sustainability, the emphasis should not be restricted to the Green Agenda 21 of Social, Environmental and Economic needs alone but be integrated with the Brown Agenda 21 of Equitable, Viable and Bearable factors because social justice and human welfare is paramount to environmental and economic matters. Thus it is better to have responsible people today who will save the environment for the future than to have a better environment now but producing people that will destroy it in the future see table 1.0

The concept proposed in this research is based on the view of the researchers that if the triple bottom line agenda 21 concept is interwoven with the triple brown agenda 21 , a balanced holistic campus sustainability integration of the Anthropocentrism, ecocentrism, human welfare and fairness issues to address inequities in service deliveries in the University will be addressed. In essence the economic, Social and environmental should be integrated with the viable, bearable and equitable factors as shown in table 1 and figure 2 below. Equitable condition seeks for social and economic justice because poverty and inequality results in ecological and social crises. It provides basic needs and opportunity to all with progress to meet needs and equitable access to resources within bond of ecological possibilities. Viable condition improves people and social equity at the same time reducing 
risk and ecological scarcities. It is development with realistic inspiration and cooperation for prosperity, politics and ethical principles. That is strategies that are economic, social and environmentally viable for short and long terms. The bearable condition is to enable the earth to endure development and growth greed to avoid crisis [8].

Table 1: The proposed holistic approach to campus sustainability

\begin{tabular}{|c|c|c|c|c|c|}
\hline $\begin{array}{l}\text { Social needs } \\
\text { "people" }\end{array}$ & $\begin{array}{c}\text { Environmental } \\
\text { needs } \\
\text { "planet" }\end{array}$ & $\begin{array}{c}\text { Economic } \\
\text { needs } \\
\text { "profit" }\end{array}$ & $\begin{array}{l}\text { Equitable } \\
\text { condition }\end{array}$ & $\begin{array}{c}\text { Viable } \\
\text { condition }\end{array}$ & $\begin{array}{l}\text { Bearable } \\
\text { condition }\end{array}$ \\
\hline $\begin{array}{l}\text { Human capital. } \\
\text { Standard of } \\
\text { Living. } \\
\text { Education. } \\
\text { Community } \\
\text { equal } \\
\text { opportunity. } \\
\text { Social } \\
\text { responsibility, } \\
\text { development } \\
\text { and equity. } \\
\text { Well-being of } \\
\text { corporate labor. } \\
\text { Enhance human } \\
\text { comfort. Health } \\
\text { and overall } \\
\text { quality of life. } \\
\text { Beneficial to } \\
\text { community and } \\
\text { region. Human } \\
\text { system fairness. }\end{array}$ & $\begin{array}{l}\text { Natural capital. } \\
\text { Natural resource } \\
\text { use. } \\
\text { Environmental } \\
\text { management. } \\
\text { Pollution } \\
\text { prevention. } \\
\text { Sustainable } \\
\text { environment } \\
\text { practice. Reduce } \\
\text { environmental } \\
\text { and climatic } \\
\text { impact. Reduce } \\
\text { ecological } \\
\text { footprint. } \\
\text { Reduce energy } \\
\text { and water waste. } \\
\text { Environmental } \\
\text { conservation. } \\
\text { Biodiversity } \\
\text { protection. } \\
\text { Environmental } \\
\text { justice. }\end{array}$ & $\begin{array}{l}\text { Financial } \\
\text { capital. Profit. } \\
\text { Cost Saving. } \\
\text { Economic } \\
\text { growth. } \\
\text { Research \& } \\
\text { development. } \\
\text { Fewer } \\
\text { resources. } \\
\text { Improve } \\
\text { employee } \\
\text { productivity. } \\
\text { Economic } \\
\text { value. Cost } \\
\text { savings. } \\
\text { Economic } \\
\text { growth. } \\
\text { Business sense. } \\
\text { Economy and } \\
\text { health. } \\
\text { Prosperity. } \\
\text { Priority. } \\
\text { Reduce } \\
\text { operating cost. } \\
\text { Money, money } \\
\text { and money. }\end{array}$ & $\begin{array}{l}\text { Business ethics. } \\
\text { Fair trade. } \\
\text { Workers right. } \\
\text { Social } \\
\text { investment } \\
\text { management. } \\
\text { Environmental } \\
\text { justice. } \\
\text { Reasonable } \\
\text { objective for all. }\end{array}$ & $\begin{array}{l}\text { Efficiency in } \\
\text { energy \& } \\
\text { water. } \\
\text { Incentives for } \\
\text { natural } \\
\text { resources } \\
\text { utilization. }\end{array}$ & $\begin{array}{l}\text { Environmental } \\
\text { justice. Natural } \\
\text { resources } \\
\text { stewardship } \\
\text { locally and } \\
\text { globally. Crisis } \\
\text { management. } \\
\text { Energy } \\
\text { efficiency. } \\
\text { Subsidies } \\
\text { investment. } \\
\text { Climate change } \\
\text { control. Safety } \\
\text { and health. } \\
\text { Biodiversity. }\end{array}$ \\
\hline
\end{tabular}

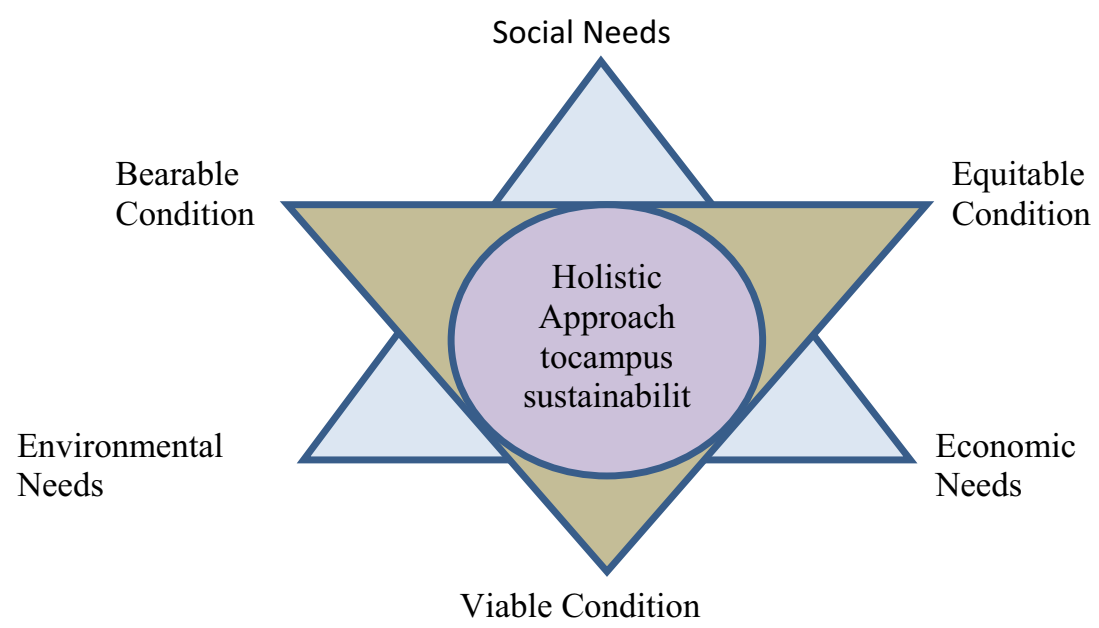

Figure 2: Components of the holistic approach to campus sustainability 
The method adopted for the study relied on observations of all biophysical facilities and socioeconomic activities and through the use of literature to determine the bases of equity, viability and bear ability as people interact with other resources on the campus [8].

\section{Conclusion}

The paper proposed that in order to have a holistic sustainable University campus, both green and brown Agenda 21be intertwine. This will hopefully meet the sustainable development agenda of the Malaysian government before the target year of 2020. The findings of the study showed that a sustainably holistic campus can be achieved if the University improves on the integration of its environmental concern and human welfare issues. The study then recommended that UKM reduce its fossil fuel consumption, ecological foot print, GHG emission, encourage research and development on sustainable issues, encourage green campus initiatives by staff, students and business operators, new projects should be certified as being sustainable before approval and commencement as well as partnering between the university, NGOs, and green groups to promote educational programme on sustainability to students, entrepreneurs, policy makers and staff.

\section{References}

1. W.M.Wan Nur'ashiqin, A.C.Ear, A. Noraziah, L. Novel, H. Halimaton Saadiah and A. Buang, 2011. Sustainable development impact from the Socio-Environmental perspectives. World Applied Science Journal, 13: 93-98.

2. Tahmasb Maghsoudi, Mahdi Mindamadi Jamal, Farajollah Hosseini and Mahmoud Hosseini, 2010. Empowering strategies for Iranian rural people to use information and communication technology service: The case of Istahan province. World Applied Science Journal, 9(6): 581-588.

3. Brundtland Report, 1987. Our common future. The World commission for environment \& development. Madrid; Alianza Publication.

4. University Leaders for sustainable future 1992.

5. The Talloires Declaration 10 point action plan http://www.ulsf.org/programs_talloires.html retrieved 30/4/2011.

6. Sustainability Tracking Assessment and Rating Systems, 2010.Technical Manual; Version 1.0. Association for the advancement of sustainability in higher education (AASHE) Limestone; Lexington, pp1-4.

7. Lele, S., 1991. Sustainable Development" A Critical Review. World Development, 19 (6): $607-$ 621.

8. A Sohif Mat, Kamaruzzaman Sopian, Mazlin Mokhtar, Baharuddin Ali, Halimaton Saadiah Hashim, Abdul Khalim Abdul Rashid, Muhammad Fauzi Mohd Zain dan Nurakmal Goh Abdullah, 2009. Managing Sustainable Campus in Malaysia - Organisational Approach and Measures. European Journal of Social Science, 8 (2): 201-214.

9. Plessis C, 2002 Agenda 21 for sustainable construction in developing countries A discussion document, Pretoria South Africa; CSIR Building and construction technology, pp1-10.

10. Triple Bottom Line, en.wikipedia.org/wiki/triplebottomline, retrieved 02/10/2013

11. Spreckley, F., 1981. Social Audit. Leeds, UK; Beech Wood College.

12. Elkington, J. and Hailes, J., 1987. The Triple Bottom Line; Cannibals of the forks, Great Britain: Pergamon Press.

13. Velaquez, I., Munguia, N., Platt, A., and Taddei, J., 2006. Sustainable University: what can be matter? Journal of cleaner production, 14: 810-819. 
14. Ayers, J., 2010. How to assess the sustainability at school sites, Campus sustainability planning network. http//www. Campus sustainability.info/forum/topics/how-to-asses-the. Retrieved $04 / 03 / 2011$

15. Norton, R. K., Brix, A., Brydon, T., Davidian, E., Dinse, K., danVidyarthi, S. 2007. Transforming the University Campus into Sustainable Community. Planning for Higher Education. 35 (4): 22-39.

16. Craighton, S.H., 1999. Greening the ivory tower; improving the environmental track records of Universities, College and other institutions, Cambridge, UK; MIT Press.

17. Zuhairuse Md Darus, Abdul Khalim Abdul Rashid, Nor Atikah Hashim, Zaidi Omar, Masran Saruwono, Noraziah Mohammad, 2009. Development of sustainable campus: UniversitiKebangsaan Malaysia planning and strategy, WSEAS Transaction on environment and development 5 (3): 273-282. 